\title{
KEMITRAAN USAHA SEBAGAI UPAYA MENINGKATKAN DAYA SAING UKM (USAHA KECIL MENENGAH) \\ (STUDI DI PERKAMPUNGAN INDUSTRI KECIL (PIK) JAKARTA TIMUR)
}

\author{
Endang Sri Rahayu*
}

\begin{abstract}
This research aimed to analyze the Partnership and Competitiveness of Small and Medium Industri (UKM) in the Small Industrial Township (PIK), East Jakarta Municipality. This research, conducted with survey. The results of this study indicated that there were (1) positive relationships between Partnerships with UKM Competitiveness; (2) Partnerships have proven a significant relationship with the Competitiveness of gaining market; (3) Partnership and Competitiveness has strengths and weaknesses in the face of market.
\end{abstract}

Keyword: Partnership, Competitiveness, UKM

\section{PENDAHULUAN}

Dalam rangka menghadapi era pasar bebas semakin ketat, pelaku ekonomi menghadapi persaingan yang sangat kuat terutama persaingan dari produk sejenis dari luar negeri yang dapat dijangkau dengan mudah dan murah. Kondisi ini memaksa para pelaku ekonomi di Indonesia terutama sektor usaha kecil dan menengah memaksimalkan segala daya agar bisa bertahan dan dapat merebut pasar. Sejarah telah menunjukkan pada waktu terjadi krisis moneter di Indonesia pada tahun 1997/1998, sektor usaha kecil dan menengah yang menjadi penyelamat bangsa Indonesia, kelompok usaha ini tetap eksis dan dapat dikatakan terlalu

* Endang Sri Rahayu. Dosen Fakultas Ekonomi Universitas Negeri Jakarta. banyak PHK (Pemutusan Hubungan Kerja).

Ada beberapa penyebab yang membuat sektor usaha kecil dan menengah ini bisa bertahan dimasa krisis, salah satu penyebabnya sektor ini tidak menggunakan bahan baku yang berasal dari luar negeri, jadi kenaikan harga dollar tidak merupakan beban biaya, malahan jika produknya diekspor mereka mendapatkan keuntungan dari naiknya harga dollar. Selain hal itu sektor ini juga umumnya mendapatkan pinjaman berasal dari pinjaman dalam negeri, sedangkan sektor industri/usaha besar sebagian mendapatkan dana pinjaman dan bahan baku dari luar negeri, sehingga depressiasi rupiah, membawa dampak pada beban biaya produksi sehingga banyak perusahaan yang memPHK karyawannya, bahkan sebagian menutup usahanya. 
Kenyataan tersebut menunjukkan bahwa posisi usaha kecil dan menengah yang biasa disebut dengan nama UKM(usaha Kecil Menengah) sangat penting untuk memperkokoh perekonomian nasional. Ketika usaha besar masih berkutat dengan ketergantungan pada pinjaman luar negeri yang semakin membengkak pada saat kritis, UKM yang fleksibel justru tidak terpengaruh, hal ini diperkuat oleh kajian dari Technical Assistant Asian Development Bank 2001 di Semarang dan Medan yang melakukan survey terhadap UKM sebanyak 500 ,menunjukkan bahwa 78\% UKM menyatakan tidak terkena dampak krisis moneter (I Wayan Dipta, 2005), UKM mampu menyerap lebih dari $50 \%$ tenaga kerja yang ada di Indonesia.

Untuk itu pengadaan sentra UKM di beberapa daerah dapat mendorong terbentuknya suatu jaringan kerja yang efektif serta terjaringnya system kemitraan yang efisien yang pada akhirnya akan meningkatkan daya saing usaha UKM. Sentra UKM di Jakarta berada di Perkampungan Industri Kecil (PIK) yang berada di Jln Penggilingan Cakung Jakarta Timur, yang terdiri dari 495 UKM yang terbagi dalam 5 jenis usaha yaitu konveksi,logam,kulit,meubel dan aneka komoditi. Untuk menaikkan daya saing banyak program kemitraan yang ditawarkan pemerintah, namun tidak semua ikut serta dalam kemitraan, di PIK hanya tercatat 48 UKM konveksi yang bermitra dengan UKM lainnya, Koperasi dan lembaga keuangan lain
(Dini, 2009). Kemitraan merupakan salah satu upaya agar usaha tetap berjalan dan mampu bersaing untuk merebut pasar. Seperti kita ketahui bahwa UKM dan Koperasi pada umumnya adalah usaha yang berawal dari usaha rumahan atau usaha dengan modal kecil dan dapat dikatakan sangat rentan dalam menghadapi persaingan, apalagi untuk merebut pasar. Kemitraan Usaha dapat dilakukan dengan saling membantu pada semua aspek seperti permodalan,pemasaran, teknologi, pengembangan sumberdaya manusia, organisasi dan lainnya. Berdasarkan latar belakang masalah diatas yang menjadi masalah penelitian adalah :a) seberapa besar pengaruh Kemitraan usaha terhadap Daya saing UKM di PIK JI Penggilingan Cakung Jakarta Timur ,b) apa yang menjadi kekuatan dan kelemahan Daya saing UKM di PIK dan c)apa saja yang menjadi kendala dalam Kemitraan Usaha. Adapun tujuan Penelitian adalah: 1) Mengkaji Kemitraan usaha dalam rangka meningkatkan Daya saing UKM ,2)Menganalisis Daya saing UKM di PIK JI Penggilingan Cakung Jakarta Timur,3)Menganalisis Kemitraan UKM di PIK JI Penggilingan Cakung Jakarta Timur.

\section{Kegunaan Penelitian}

Bagi peneliti, penelitian ini diharapkan dapat dijadikan sebagai bahan evaluasi bagi Koperasi, agar UKM/Koperasi dapat menjadi lembaga yang berkelanjutan dan mampu menopang perekonomian. Selain itu, penelitian ini diharapkan dapat memberikan sumbangsih dalam 
khasanah pengetahuan dan menjadi topik penulisan untuk kajian lebih lanjut.

\section{DESKRIPSI TEORI Hakikat Usaha kecil menengah}

Usaha kecil dapat dikatakan sebagai suatu bentuk perwujudan dari ekonomi kerakyatan, karena menurut definisi, karakteristik dan implementasinya dalam kegiatan ekonomi sangat erat hubungannya dengan ciri khas masyarakat Indnesia. Menurut Sutoyo, struktur usaha kecil sebagai organisasi sederhana, karakter yang sederhana tanpa elaborasi, memiliki hierarki kecil,aktivitasnya hanya sedikit diformalkan, sangat sedikit menggunakan proses perencanaan, dan jarang sekali mengadakan pelatihan karyawan dan manajer, sukar membedakanasset pribadi dan perusahaan, serta sistem akuntansi kurang baik,bahkan terkadang tidak memiliki (Heru Sutojo, 2004). Dari pengertian tersebut dapat diduga bentuk dan jenis usaha, kemampuan modal, dan lainnya yang berhubungan dengan pengembangan usaha, masih sangat sederhana, akan tetapi dapat menjadi dasar untuk berkembang menjadi usaha menengah .

Adapun pengertian usaha
kecil dan menengah yang
dikemukakan oleh Kementrian Negara Koperasi, oleh Biro Pusat Statistik,dan Undang Undang No 9/1999 adalah sebagai berikut:

1) Usaha Kecil dan Menengah (UKM). Menurut Kementrian Negara Koperasi dan Usaha Kecil
(2006-2007),Usaha Kecil adalah kegitaan ekonomi yang dilakukan oleh perseorangan atau rumah tangga maupun suatu badan yang bertujuan untuk memproduksi barang atau jasa untuk diperniagakan secara komersial dan mempunyai omzet penjualan sebesar 1 (satu) milyar atau kurang.Sedangkan usaha menengah adalah kegiatan ekonomi yang dilakukan oleh perseorangan atau rumah tangga maupun suatu badan yang bertujuan untuk memproduksi barang atau jasa untuk diperniagakan secara komersial dan mempunyai omzet penjualan lebih dari 1 (satu) milyar.

2) Menurut Biro Pusat Statistik. Usaha kecil adalah usaha yang memiliki karyawan $5 \quad-19$ orang,usaha menengah adalah usaha yang mempunyai karyawan 20 - 99 orang

3) Undang-undang NO $9 / 1995$. Usaha kecil adalah usaha yang memiliki kekayaan bersih paling banyak Rp 200 juta (tidak termasuk tanah dan bangunan usaha) atau memliki hasil penjualan paling banyak 1 milyar/tahun. Usaha menengah adalah usaha yang untuk sektor industri memiliki total asset paling banyak 5 milyar dan untuk sektor non industri, memiliki kekayaan bersih paling banyak RP 600 juta tidak termasuk tanah dan bangunan tempat usaha, memiliki hasil penjualan tahunan paling banyak 3 milyar. 
Dalam upaya membantu pengembangan usaha pemerintah mempunyai sasaran operasional yaitu: a) terciptanya iklim usaha, b) terwujudnya kualitas dan kemampuan menuju kearah organisasi yang formal, c) peningkatan kemampuan wiraswasta, manjemen tehins serta penataan dan penataan dan pemantapan kelembagaan. d)peningkatan kemampuaan dalam penguasaan,penerapan dan pemanfaatan ITI,e)peningkatan dan pemantapan keterkaitan dan kemitraan usaha yang saling menguntungkan antar pengusaha kecil, menengah dan lainnya. (Deperindag, 1997)

\section{Hakikat Kemitraan Usaha}

Kemitraan adalah jalinan kerjasama dari dua atau lebih pelaku usaha yang saling menguntungkan sebagai salah satu upaya untuk meningkatkan kesempatan UKM dalam percaturan perekonomian nasional. Menurut UU No 9/1995, kemitraan adalah kerjasama antara usaha kecil dengan usaha besar atau usaha menengah disertai dengan pembinaan dan pengembangan yang berkelanjutan oleh usaha besar atau usaha menengah dengan memperhatikan prinsip saling memerlukan, saling memperkuat dan saling menguntungkan, selanjutnya menurut Julisar Annaf (2007), kemitraan usaha dilaksanakan dengan disertai pembinaan dan pengembangan dalam salah satu atau lebih bidang produksi dan pengelolaan,pemasaran, permodalan, sumberdaya manusia dan teknologi.
Dengan demikian pemahaman tentang kemitraan usaha didasarkan kerja sama antar pelaku ekonomi dalam berbagai aspek usaha yang saling menguntungkan,tidak saling merugikan dengan mengikuti aturan dan memahami etika bisnis bagi pelaku kemitraan. Kemitraan berasal dari kata mitra yang berarti teman, kawan-kawan pasangan kerja, rekan kerja. Sedangkan menurut kamus Pusat Pembinaan dan Pengembangan bahasa Depdikbud Bahasa Indonesia (1991), kemitraan artinya perihal hubungan atau jalinan kerjasama sebagai mitra. Seperti yang tercantum dalam UndangUndang No 9 tahun 1995: "kemitraan adalah kerjasama antara usaha kecil dengan usaha besar atau usaha menengah disertai dengan pembinaan dan pengembangan yang berkelanjutan oleh usaha besar atau usaha menengah dengan memperhatikan prinsip-prinsip saling memerlukan, saling memperkuat dan saling menguntungkan".

Julisar Annaf (2007) juga mengatakan bahwa kemitraan usaha dilaksanakan dengan disertai pembinaan dan pengembangan dalam salah satu atau lebih bidang produksi, dan pengolahan, pemasaran, permodalan, sumberdaya manusia dan teknologi. Senada dengan itu, Gunawan Sumodiningrat (1997) mengungkapkan bahwa "kemitraan dalam dunia usaha adalah hubungan antara pelaku ekonomi yang didasarkan atas ikatan usaha yang saling menguntungkan dalam hubungan kerja yang sinergis." Dengan demikian dapat dikatakan 
bahwa kemitraan adalah hubungan kerjasama yang berusaha untuk saling menguntungkan dengan tidak merugikan pihak manapun dan tetap dalam hubungan yang terjaga dan sinergis.

Misi utama pemerintah dalam mengambil kebiijakan kemitraan adalah untuk mengatasi ketimpangan dalam kesempatan berusaha, ketimpangan pendapatan, pemerataan antar wilayah kota dan desa. Dalam mengatasi ketimpanganketimpangan kesenjangan ini salah satu adalah melalui kemitraan usaha antar usaha besar dan usaha menengah dan usaha kecil, seperti yang diungkapkan Saragih: "kemitraan pada dasarnya adalah bentuk kegiatan internalisasi (meminimalkan pengaruh kurang sehat atau eksternalitas negative) dari kesenjangan dalam persaingan usaha.

Jadi melalui kemitraan diharapkan secara cepat dapat terjadi simbiosis mutualistik. Proses yang dimulai dengan perencanaan kemudian rencana itu diimplementasikan dan selanjutnya dimonitor dan dievaluasi terus emnerus oleh pihak yang bermitra. Menurut John L.Marioti (1993): kemitraan merupakan suatu rangkaian proses yang dimulai dengan mengenal calon mitranya, mengetahui posisi keunggulan dan kelemahan usahanya, memulai membangun strategi, melaksanakan dan terus memonitor dan mengevaluasi sampai target sasaran tercapai. Proses ini harus benar benar dicermati sejak awal sehingga permasalahan yang timbul dapat diketahui baik besarnya permasalahan maupun langkah langkah yang perlu diambil.

Sebagai implementasi dari hubungan kemitraan tersebut dilaksanakan melalui pola-pola kemitraan yang sesuai sifat atau kondisi dan tujuan usaha yang dimitrakan dengan menciptakan iklim usaha yang kondusif, baik di dalam pembinaan maupun pelaksanaan operasionalnya. Pola-pola kemitraan itu antara lain:

1) Pola inti plasma, Menurut penjelasan pasal 27 huruf (a) Undang-Undang Nomor 9 Tahun 1995, yang dimaksud dengan pola inti plasma adalah "hubungan kemitraan antara usaha kecil dengan usaha menengah atau usaha besar sebagai inti membina dan mengembangkan usaha kecil yang menjadi plasmanya dalam menyediakan lahan, penyediaan sarana produksi, pemberian bimbingan teknis manajemen usaha dan produksi, perolehan, penguasaan dan peningkatan teknologi yang diperlukan bagi peningkatan efisiensi dan produktivitas usaha".

2) Pola SubKontrak,menurut penjelasan pasal 27 huruf (b) Undang - Undang Nomor. 9 Tahun 1995 bahwa "pola subkontrak adalah hubungan kemitraan antara Usaha Kecil dengan Usaha Menengah atau Usaha Besar, yang didalamnya Usaha Kecil memproduksi komponen yang diperlukan oleh 
Usaha menengah atau Usaha Besar sebagai bagian dari produksinya"

3) Pola Dagang Umum, menurut penjelasan Pasal 27 huruf (c) Undang - Undang Nomor. 9 tahun 1995, Pola Dagang Umum adalah "hubungan kemitraan antara Usaha Kecil dengan Usaha Menengah atau Usaha Besar, yang di dalamnya Usaha Menengah atau Usaha Besar memasarkan hasil produksi Usaha Kecil atau Usaha Kecil memasok kebutuhan yang diperlukan oleh Usaha Menengah atau Usaha Besar mitranya".

4) Pola Keagenan, berdasarkan penjelasan Pasal 27 huruf (e) Undang - undang Nomor. 9 Tahun 1995, pola keagenan adalah "hubungan kemitraan, yang di dalamnya Usaha Kecil diberi hak khusus untuk memasarkan barang dan jasa Usaha Menengah atau Usaha Besar mitranya".

5) Waralaba, menurut penjelasan Pasal 27 Huruf (d) Undang Undang Nomor. 9 Tahun 1995, Pola Waralaba adalah "hubungan kemitraan, yang di dalamnya pemberi waralaba memberikan hak penggunaan lisensi, merk dagang, dan saluran distribusi perusahaannya kepda penerima waralaba dengan disertai bantuan bimbingan manajemen".

Adapun manfaat melakukan kemitraan usaha dibagi dalam dua sudut pandang yaitu: sudut pandang badan usaha/ perusahaan:

a. Membagi resiko dan biaya b. Menyatukan dan mendapatkan sinergi sumberdaya

c. Meningkatkan kemampuan permodalan

d. Memaksimalkan dalam pemanfaatan fasilitas dan produk sampingan

e. Memanfaatkan teknologi baru

f. Mengoptimalkan kemampuan

Sudut pandang stategis

a. Mengantisipasi dalam menghadapi pertumbuhan industri

b. Memenangkan persaingan

c. Mendapatkan akses dalam pasar global

d. Meningkatkan transfer teknologi

e. Melakukan diversifikasi usaha

\section{METODOLOGI PENELITIAN}

Metode yang digunakan dalam penelitian ini adalah metode survey dengan pendekatan korelasional. Populasi dalam penelitian ini adalah seluruh UKM yang berada di Perkampungan Industri Kecil yang berjumlah 495 unit. Sedangkan populasi terjangkaunya adalah UKM yang bergerak di sentra konveksi atau garmen yang bermitra yang berjumlah 48 unit. Tekhnik pengambilan sampel dengan menggunakan tehnik sensus, artinya semua anggota populasi terjangkau dijadikan sampel (Sugiyono, 1997). Instrument pengumpulan data yang digunakan adalah kuesioner. Tehnik analisa data terdiri dari dua bagian yaitu analisis deskripsi dan analisis statistik korelasi sederhana. 


\section{HASIL PENELITIAN}

Hasil penelitian diperoleh persamaan $Y=48,13+0,50 X$ yang memberikan informasi bahwa setiap kenaikan satu satuan skor Kemitraan usaha akan menyebabkan kenaikan Daya saing sebesar 0,50 pada konstanta 48,13. Berdasarkan pengujian signifikansi koefisien korelasi antara dua variable diperoleh t hitung sebesar 5,248 dan t table 1,684 (t hitung >t table), dengan demikian rxy $=0,612$ signifikan berarti dapat disimpulkan terdapat hubungan positif antara Kemitraan Usaha dengan Daya Saing Usaha UKM di Perkampungan Industri Kecil di Pulogadung Jakarta Timur. Selanjutnya besarnya kontribusi Kemitraan usaha terhadap Daya saing diperoleh koefisien korelasi (KD) 0,3745 hal ini berarti sebesar 37,45 $\%$ variasi daya saing ditentukan oleh kemitraan usaha, 62,55\% ditentukan oleh faktor lain.

\section{Analisis Kemitraan}

Data kemitraan dijaring dengan kuesioner yang disusun dengan indikator meliputi: akses modal, pengembangan ketrampilan, kemampuan manajerial, teknologi, akses pasar, dan deversifikasi usaha/produk. Dari hasil kuestioner yang memperoleh nilai tinggi adalah dalam hal: a) Kemitraan membantu UKM dalam hal akses modal, b) pengembangan ketrampilan, c) manajemen, d) diversifikasi produk, e) akses pasar. Sedangkan hasil kuesioner yang memperoleh nilai tidak maksimal adalah dalam hal: a) masalah bantuan pembiayaan/modal, b) pengembangan teknologi yang meliputi: penyediaan akses, membantu proses alih teknologi serta penerapan teknologi dan c) dalam hal bimbingan perluasan/pengembangan usaha.

\section{Analisis Daya saing}

Data daya saing dijaring dengan kuesioner yang disusun dengan indikator meliputi: ruang lingkup perusahaan, kapabilitas organisasi, kompetensi pemilik, hasil kerja dan inovasi .

Dari hasil kuestioner yang memperoleh nilai tinggi adalah: ruang lingkup perusahaan, kompetensi pemilik yang meliputi keahlian, tingkat pendidikan, volume penjualan Sedangkan hasil kuestioner yang memperoleh nilai tidak maksimal /lemah dalam hal: sistem manajemen dan organisasi, inovasi produk, akses pasar serta kesulitan dalam alat/mesin untuk produksi yang modern.

\section{KESIMPULAN DAN SARAN \\ Kesimpulan :}

1) Kemitraan Usaha terbukti memiliki hubungan yang signifikan dengan daya saing UKM dalam merebut pasar.

2) Kontribusi Kemitraan memberikan sumbangan sekitar $\quad 37,45 \%$ terhadap daya saing.

3) Kekuatan Daya saing meliputi ruang lingkup perusahaan, kompetensi pemilik yang meliputi keahlian, tingkat pendidikan, volume penjualan sedangkan kelemahannya manajemen dan organisasi, 
inovasi produk, akses pasar serta kesulitan dalam alat/mesin untuk produksi yang modern.

4) Kendala dalam Kemitraan Usaha meliputi masalah a) bantuan pembiayaan/modal, b) pengembangan teknologi yang meliputi: penyediaan akses, membantu proses alih teknologi serta penerapan teknologi dan c) dalam hal bimbingan perluasan/ pengembangan usaha.

\section{Saran}

1. UKM harus terus meningkatkan daya saing usaha dengan didasarkan pada kemitraan usaha uang kuat sehingga membuat UKM mampu bersaing.

2. Dari hasil kajian instrument penelitian beberapa kelemahan daya saing merupakan catatan yang harus diperhatikan oleh pihak terkait.

3. Kekuatan dan kelemahan Kemitraan Usaha merupakan hal yang perlu diperhatikan, baik dari pihak yang membina peningkatan UKM (Deperindag) maupun pihak lain dan perlu segera ditindak lanjuti kerjasama yang lebih riel dengan Pemda DKI.

\section{DAFTAR PUSTAKA}

Darmawan, Adi. 2006. Dampak kemitraan terhadap perkembangan usaha kecil. Jakarta : Universitas Indonesia (hasil tesis tidak untuk dipublikasikan)
Dipta, I Wayan. 2005. Pengembangan Klaster Bisnis Untuk Memperkuat Daya Saing Usaha Kecil dan Menengah, Jakarta: Jurnal Infokop no 27.

Hafsah, Jafar. 1994. Kemitraan usaha, konsepsi dan strategi. Jakarta.

Klara, Markovics. 2005. Competitiveness of domestic small and medium enterprises in the europan union. European integration studies: Miskolc.

Porter, Michael E. 1997. Keunggulan bersaing, menciptakan dan mempertahankan kinerja unggul. Jakarta: Binarupa aksara

Sartika Partomo, Tiktik dan Rahman Sudjono. 2002. Ekonomi skala kecil / menengah dan koperasi. Jakarta : Ghalia Indonesia :

Sofia, Hani. "APBN semakin tak berpihak pada Koperasi dan UKM". Januari 2009

Statistik Usaha Kecil dan Menengah (UKM) tahun 2006 - 2007. Kemitraan Negara Koperasi dan Usaha Kecil dan Menengah

Sukidjo, 1997. Manajemen Koperasi, Jakarta :Dikbud PGSM.

Sumodiningrat, Gunawan. 1997. Strategi penguatan kelembagaan kemitraan sebagai upaya pemberdayaan ekonomi rakyat. Bogor.

Tambunan, Tulus. 2002. Ukuran daya saing koperasi dan UKm. Jakarta:Pusat Studi Industri dan UKM Universitas Trisakti , Undang - undang RI No 9 Tahun 1995 tentang Kemitraan. 